\title{
PERANCANGAN SISTEM INFORMASI ADMINISTRASI PADA PENDIDIKAN ANAK USIA DINI AL-IKHLAS BERBASIS JAVA
}

\author{
Farchan Fauzan Noor ${ }^{1}$, Budi Santoso ${ }^{2}$, Lies Sunarmintyastuti ${ }^{3}$ \\ ${ }^{1,2,3}$ Universitas Indraprasta PGRI Jakarta \\ Jl. Raya Tengah, Gedong, Pasar Rebo, Jakarta Timur

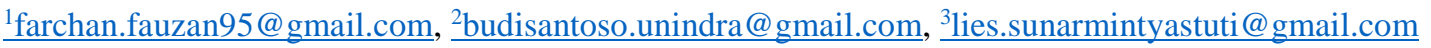

\begin{abstract}
ABSTRAK
Permasalahan yang terdapat pada PAUD Al-Ikhlas adalah pengolahan datanya masih dilakukan secara manual. Dari proses pembayaran yang masih menggunakan kartu bayaran dan penilaian harian yang masih ditulis pada kertas. Metode pengolahan data tersebut masih kurang efektif sehingga kurangnya efisien waktu, perhitungan data, ketepatan data dan keakuratan data. Dalam pengolahan informasi administrasi data guru dan data murid masih menggunakan input secara manual dan belum terorganisir dengan baik karena belum mempunyai database. Penelitian ini bertujuan untuk merancang sistem informasi administrasi secara terkomputerisasi agar memudahkan pengguna dalam mengolah data dan proses pembayaran, penilaian harian, data guru, dan data murid sehingga data yang didapat lebih akurat dan tepat sehingga tidak terjadi kesalahan dalam proses pendataan. Metode yang digunakan dalam penelitian ini yaitu metode grounded dengan menggunakan metode pengumpulan data nya melalui observasi, wawancara dan studi pustaka. Hasil dari penelitian yang telah dilakukan adalah sebuah sistem informasi administrasi yang telah terkomputerisasi.
\end{abstract}

Kata Kunci: Administrasi, PAUD, Java, MySQL, Netbeans.

\begin{abstract}
The problem in PAUD Al-Ikhlas is that the data processing is still done manually. From the payment process that still uses a payment card and the daily assessment that is still written on paper. The data processing method is still less effective so that the lack of time efficiency, data calculation, data accuracy and data accuracy. In processing administrative information, teacher data and student data still use manual input and are not well organized because they do not have a database. This study aims to design a computerized administrative information system to make it easier for users to process data and process payments, daily assessments, teacher data, and student data so that the data obtained is more accurate and precise so that there are no errors in the data collection process. The method used in this research is the grounded method using data collection methods through observation, interviews and literature study. The result of the research that has been done is an administrative information system that has been computerized.
\end{abstract}

Key Word: Administration, PAUD, Java, MySQL, Netbeans.

\section{PENDAHULUAN}

PAUD Al-Ikhlas merupakan kelompok bermain yang mewujudkan generasi muslim yang cendikia, sehat dan mandiri. Namun terdapat beberapa masalah pada pengolahan data yang masih dilakukan secara manual. Dari proses pembayaran yang masih menggunakan kartu bayaran dan penilaian harian yang masih ditulis pada kertas. Metode pengolahan data tersebut masih kurang efektif sehingga kurangnya efisien waktu, perhitungan data, ketepatan data dan keakuratan data. Dalam pengolahan informasi administrasi data guru dan data murid masih menggunakan input secara manual dan belum terorganisir dengan baik karena belum mempunyai database. "Perancangan adalah langkah pertama dalam tingkat penambahan implementasi produk atau sistem.
Perancangan adalah proses penerapan berbagai teknologi dan prinsip, yang bertujuan untuk mendefinisikan secara rinci peralatan, proses, atau sistem yang memungkinkan realisasi fisik". (Nadeak et al., 2016).

Penelitian ini bertujuan untuk merancang sistem informasi administrasi secara terkomputerisasi agar memudahkan pengguna dalam mengolah data dan proses pembayaran, penilaian harian, data guru, dan data murid sehingga data yang didapat lebih akurat dan tepat sehingga tidak terjadi kesalahan dalam proses pendataan. "Sistem adalah sekelompok subsistem, komponen yang bekerja sama untuk menghasilkan output yang telah ditentukan dengan tujuan bersama". (Mulyani, 2016). "Informasi adalah data yang 
telah diklasifikasikan atau diolah atau dinterprestasikan untuk digunakan dalam proses pengambilan keputusan". (Sutabri, 2012). "Sistem informasi adalah prosedur formal tempat dimana data dikelompokkan, diolah menjadi informasi dan didistribusikan untuk pengguna". (Kadir, 2014). "Administrasi adalah keseluruhan proses dari dua orang atau lebih yang bekerja sama berdasarkan suatu rasionalitas tertentu untuk mencapai suatu tujuan yang telah ditentukan". (Herliana, 2016). "Data Flow Diagram adalah model atau proses logika data, yang digunakan untuk menggambarkan dari mana data itu berasal, dari mana ia keluar dari sistem, di mana data disimpan, proses apa yang menghasilkan data, dan interaksi antara data yang disimpan dan proses yang diterapkan pada data". (Muslihudin \& Oktafianto, 2016).

Adapun manfaat penelitian ini yaitu dapat mempermudah sistem administrasi PAUD AlIkhlas dalam menyimpan data dan menginput dalam membuat laporan. Perancangan sistem aplikasi pengolahan data pasien dibangun dengan menggunakan bahasa pemrograman Java Netbeans dengan database MySQL. "Java merupakan bahasa pemrograman objek murni karena semua kode program terkandung dalam kelas". (Sukamto \& Shalahuddin, 2013). "Netbeans adalah aplikasi Integrated Development Environment (IDE) yang menggunakan bahasa pemrograman java sun microsystems yang berjalan di swing". (Nofriadi, 2015). "Basis data adalah pengumpulan data yang terkait secara logis dan interpretasi data, untuk menemukan data yang dibutuhkan oleh organisasi". (Indrajani, 2015). "MySQL adalah software RDMS (server database) dapat dikelola database dengan sangat cepat, dapat menampung data dalam jumlah yang sangat besar, dapat diakses oleh banyak pengguna (multi-user), dan dapat menjalankan suatu proses secara sinkron atau bersamaan (multi-threaded)". (Raharjo, 2015).

\section{METODE PENELITIAN}

Lokasi penelitian serta pengamatan dalam proses pengambilan data ini bertempat di PAUD Al-Ikhlas yang beralamat di Jalan Desa Putra No.33/B, Srengseng Sawah, Jakarta Selatan. Data-data tersebut diproses sehingga dapat dimanfaatkan dalam penelitian.

Metode penelitian yang dilakukan oleh penulis menggunakan metode grounded. "Metode grounded adalah metode penelitian yang didasarkan pada fakta. Menggunakan analisis komparatif untuk menggeneralisasi mendemonstrasikan, menetapkan konsep, membuktikan teori, mengembangkan teori, serta mengumpulkan dan menganalisis data pada saat yang bersamaan". (Trisnadi, 2020).

Adapun pengumpulan data yang digunakan oleh penulis adalah sebagai berikut:

Observasi: Penulis melakukan observasi secara langsung di tempat penelitian. Penulis mengamati bagaimana proses administrasi PAUD yang sedang berjalan serta mencatat data-data yang diperlukan untuk penelitian lebih lanjut.

Wawancara: Penulis melakukan wawancara dengan tatap muka langsung dengan Kepala Sekolah dan Bendahara. Penulis meminta data yang dibutuhkan seperti data guru, data murid, penilaian harian dan pembayaran SPP.

Studi Kepustakaan: Metode pengumpulan data dengan studi kepustakaan dilakukan untuk mendapatkan data yang diperlukan dengan cara mempelajari dari buku dan internet sebagai acuan dalam merancang aplikasi.

Dalam pengembangan sistem yang terdapat pada PAUD Al-Ikhlas, penulis melakukan langkah-langkah yang ada pada model waterfall yang terdiri dari perencanaan, pemodelan, dan konstruksi dengan rincian sebagai berikut:

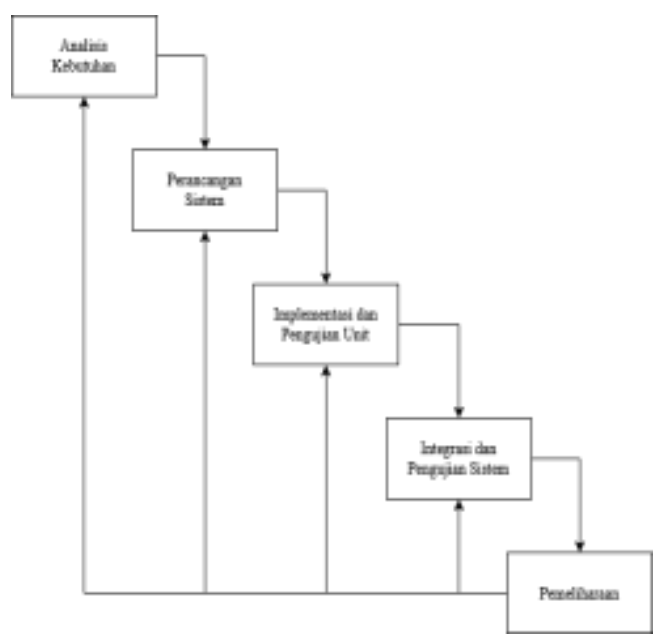

Gambar 1. Permodelan Waterfall 
Tahap Analisis Kebutuhan

Analisis kebutuhan berguna untuk mendapatkan data-data yang akan digunakan sebagai masukan dari suatu sistem dan untuk memperoleh data yang berhubungan dengan tugas akhir ini. Proses perancangan sistem aplikasi administrasi dimulai dari memahami pengguna, apa saja yang pengguna inginkan.

\section{Tahap Perancangan Sistem}

Perancangan sistem bertujuan untuk merancang sistem yang akan dibuat agar dapat diimplementasikan dengan kebutuhan pengguna. Langkah - langkah yang dilakukan dalam Perancangan Sistem Informasi Administrasi pada Pendidikan Anak Usia Dini Al-Ikhlas berbasis Java adalah:

Merancang database

a. Membuat tabel - tabel data beserta primary key-nya.

b. Menentukan relationship dari setiap tabel.

c. Membuat query.

d. Membuat report yang digunakan untuk menampilkan hasil output sebelum dicetak.

e. Membuat normalisasi bila terdapat tabel data yang unnormal.

\section{Merancang antarmuka}

a. Harus memiliki jiwa seni.

b. Mengerti selera pengguna secara umum.

c. Melakukan dokumentasi rancangan agar rancangan dabat diubah.

\section{Mengembangkan antarmuka}

Dalam melakukan pengembangan terhadap antarmuka hal pertama yang harus diperhatikan adalah membangun prototype. Membangun prototype adalah cara yang berharga dalam membuat rancangan awal dan membuat demonstrasi maka sangat penting untuk melakukan pengujian kegunaan antarmuka. Dari prototype tersebut, perancang antarmuka dapat mulai membangun anatarmuka secara utuh, ketika membuat prototype, sangat penting untuk diingat bahwa prototype harus dapat dibuang setelah digunakan (disposable), tujuan pembuatan prototype adalah untuk mempercepat dan menyederhanakan visualisasi desain dan konsep alternatif, bukan untuk membangun kode yang akan digunakan sebagai bagian dari produk.Melakukan evaluasi terhadap antarmuka.
Bagian penting dari proses pengembangan adalah untuk megenali bagaimana pengguna merespon antarmuka yang sudah dibuat. Penilaian ini hendak digunakan untuk memperbaiki kekurangan pada antarmuka yang sudah terbangun. Ketentuan dalam perancangan antarmuka:

a. Buat antarmuka yang mudah dimengerti serta dipahami oleh pengguna.

b. Buat antarmuka yang konsisten.

c. Tahap Implementasi dan Pengujian Unit

d. Desain program diterjemahkan ke dalam kode menggunakan bahasa pemrograman yang telah ditentukan. Program yang dibangun langsung diuji berdasarkan unit.

e. Tahap Integrasi dan Pengujian Sistem

f. Penyatuan unit-unit program kemudian diuji secara keseluruhan (system testing).

g. Tahap Pemeliharaan

h. Mengoperasikan program di lingkungannya dan melakukan pemeliharaan, seperti penyesuaian atau perubahan karena adaptasi dengan situasi sebenarnya.

\section{HASIL DAN PEMBAHASAN}

Analisis Permasalahan

Dari hasil penelitian yang dilakukan, makan penulis dapat menganalisa permasalahan yang ada pada PAUD Al-Ikhlas yaitu proses pembayaran masih menggunakan kartu bayaran dan penilaian harian masih ditulis pada kertas, sedangkan dalam pengolahan informasi administrasi data guru dan data murid masih menggunakan input secara manual dan belum terorganisir dengan baik karena belum mempunyai database. Hal tersebut masih kurang efektif sehingga kurangnya efisien waktu, perhitungan data, ketepatan data dan keakuratan data. Serta terlalu lama dalam proses pengolahan informasi akan mengakibatkan keterlambatan dalam pengambilan keputusan.

\section{Alternatif Penyelesaian Masalah}

Berdasarkan masalah - masalah yang dihadapi dalam sistem administrasi pada PAUD Al-Ikhlas, maka penulis memberikan alternatif masalah tersebut yaitu penulis membuat sistem informasi administrasi yang dapat mengolah data pembayaran dengan cetak bukti pembayaran sebagai pengganti kartu pembayaran, membuat sistem aplikasi data penilaian dengan begitu akan menjadi lebih efisien, membuat database guru dan 
murid dapat dikelola dengan baik di dalam aplikasi administrasi.

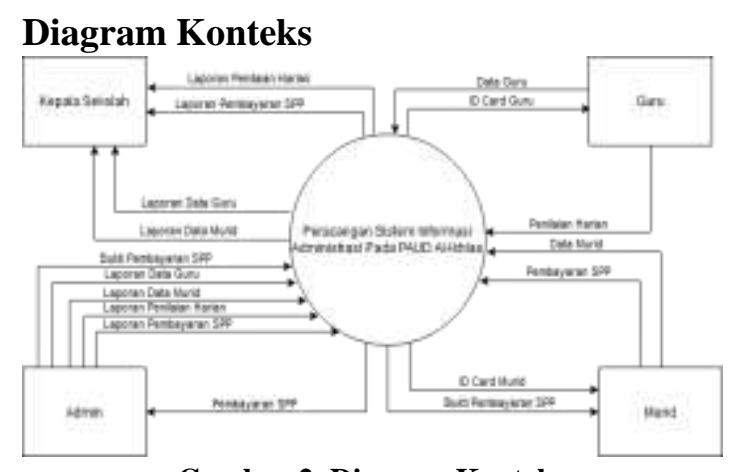

Gambar 2. Diagram Konteks

\section{Diagram Nol}

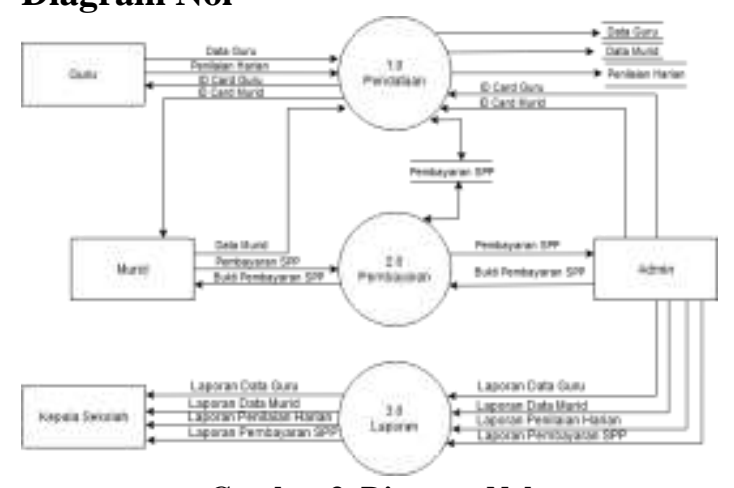

Gambar 3. Diagram Nol

\section{Entity Relationship Diagram}

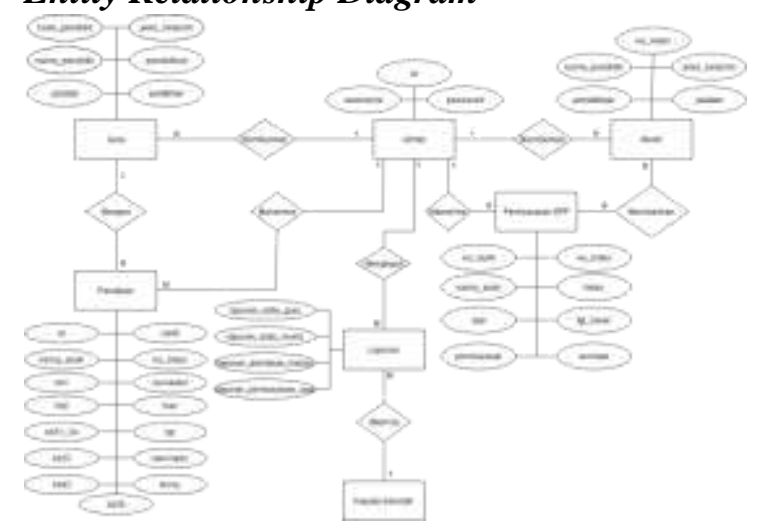

Gambar 4. Entity Relationship Diagram

\section{Tampilan Layar}

Selanjutnya penulis membuat perancangan sistem informasi administrasi dengan pemrograman bahasa Java dan IDE yang digunakan adalah NetBeans 8.2 dan database menggunakan MySQL. Berikut ini adalah tampilan dari perancangan sistem aplikasi administrasi pada Pendidikan Anak Usia Dini Al-Ikhlas:

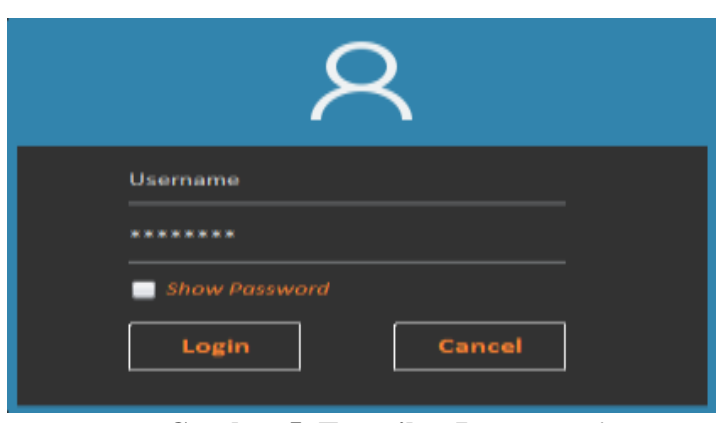

Gambar 5. Tampilan Layar Login

Tampilan form masukan login muncul pada awal program dijalankan. Pengguna dihadapkan pada kotak dialog untuk memasukan username dan password yang telah diberikan. Jika username dan password sesuai, maka tampilan akan masuk ke menu utama.

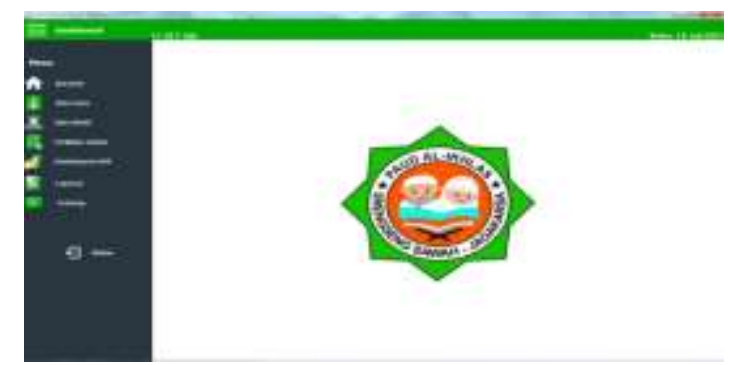

Gambar 6. Tampilan Layar Menu Utama

Tampilan layar menu utama terdapat beberapa menu diantaranya beranda, data guru, data murid, penilaian harian, pembayaran SPP, laporan, tentang, dan keluar.

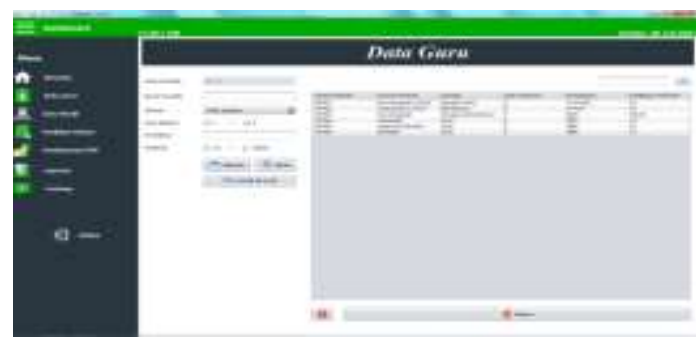

Gambar 7. Tampilan Layar Form Data Guru

Pada tampilan layar form data guru terdapat informasi data guru. Data Guru dapat di-input dan diubah oleh admin.

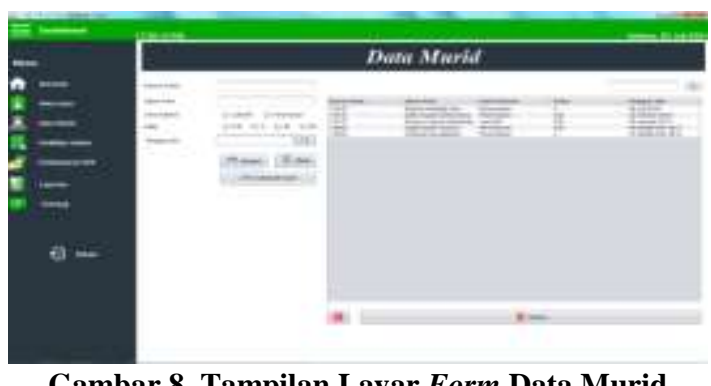

Gambar 8. Tampilan Layar Form Data Murid 
Pada form tampilan menu data murid, terdapat informasi data murid. Data murid dapat diinput dan diubah oleh admin.

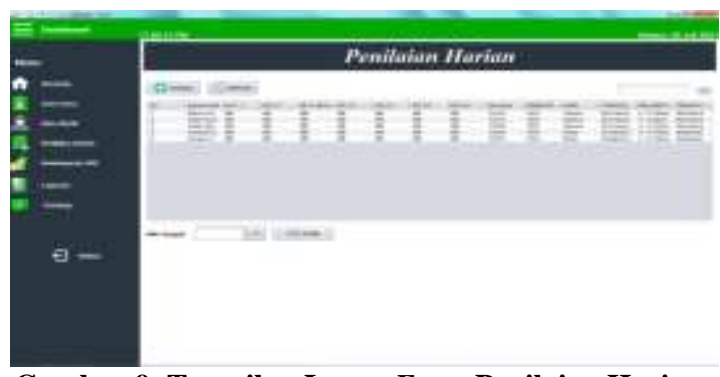

Gambar 9. Tampilan Layar Form Penilaian Harian

Pada form tampilan menu penilaian harian, terdapat informasi penilaian harian. Penilaian harian bisa ditambah oleh admin dengan pilih tombol tambah. Setelah dipilih akan keluar form tambah penilaian. Pilih tanggal sesuai pada tabel lalu pilih cetak untuk mencetak laporan penilaian harian.

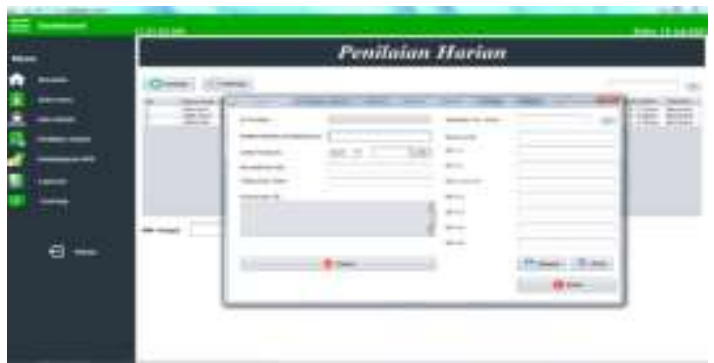

Gambar 10. Tampilan Layar Form Tambah Penilaian

Tampilan tambah penilaian merupakan form untuk meng-input nilai yang telah diberikan guru. Data penilaian dapat diubah dengan memilih salah satu data pada tabel dan secara otomatis form tambah nilai akan keluar dan sudah terisi dari data yang sudah dipilih.Tambah penilaian dapat di-input dan diubah oleh Admin.

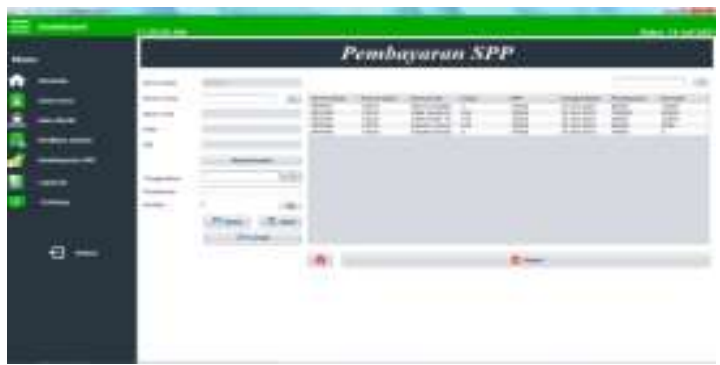

Gambar 11. Tampilan Layar Form Pembayaran SPP

Pada tampilan form pembayaran SPP, pengguna akan dihadapkan pada tampilan transaksi pembayaran dimulai dari input data murid lalu mengisi jumlah pembayaran.

Secara otomatis harga kembalian akan muncul setelah menekan button ikon kalkulator, pilih button bayar untuk menyimpan data. Pilih salah satu data pada tabel lalu pilih cetak untuk mencetak bukti pembayaran.

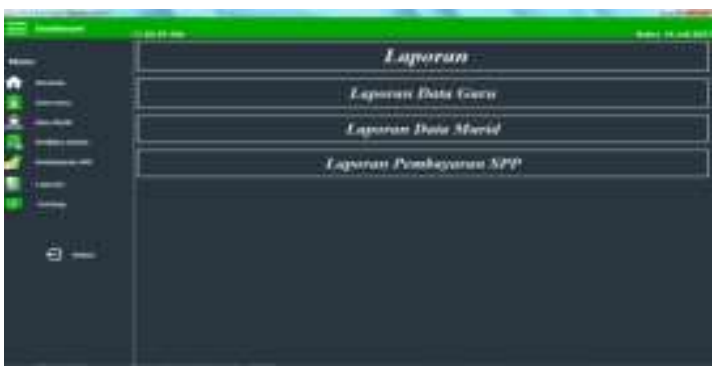

Gambar 12. Tampilan Layar Laporan

Pada tampilan layar laporan ini, admin dapat melihat laporan data guru, data murid, dan juga pembayaran SPP. Untuk mencetak data admin hanya perlu pilih tombol sesuai dengan laporan yang ingin di cetak.

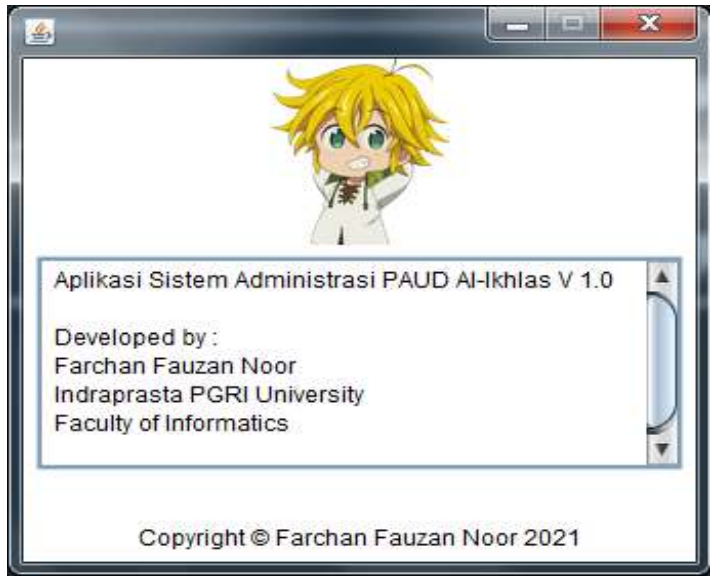

Gambar 13. Tampilan Layar Tentang

Pada tampilan form tentang ini hanya menampilkan informasi pembuat aplikasi yang dibuat pada tahun 2021 .

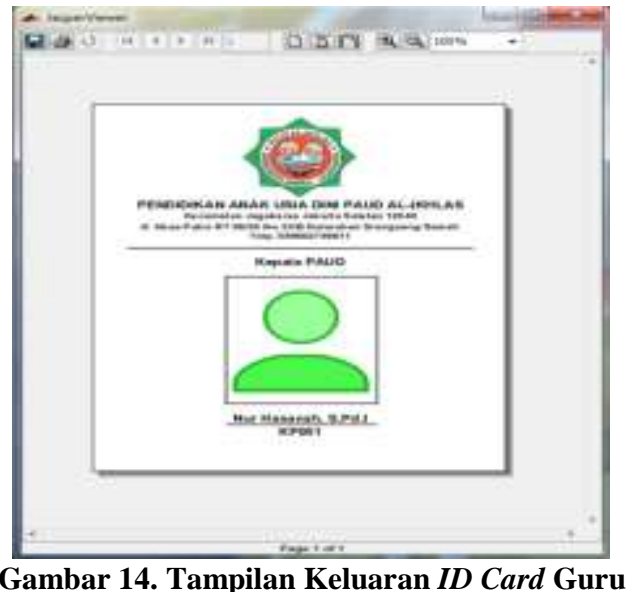


Cetak ID Card guru merupakan keluaran dari proses data guru yang dipilih berdasarkan tabel data guru. ID Card guru diberikan kepada guru sesuai identitas masing-masing.

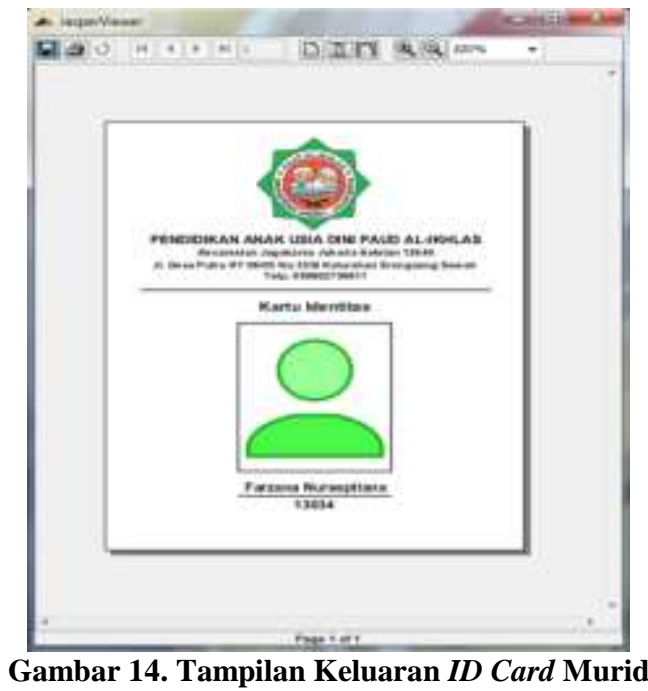

Cetak ID Card murid merupakan keluaran dari proses data murid yang dipilih berdasarkan tabel data murid. ID Card murid diberikan kepada murid sesuai identitas masing-masing.

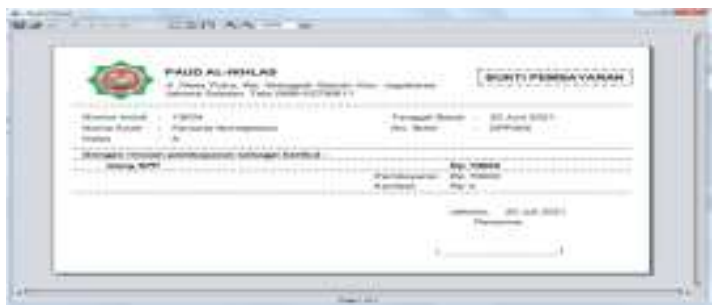

Gambar 15. Tampilan Keluaran Bukti Pembayaran SPP

Cetak bukti pembayaran merupakan keluaran dari proses pembayaran SPP yang dipilih berdasarkan tabel pembayaran SPP. Bukti pembayaran diberikan kepada orangtua murid setelah membayar uang pembayaran SPP.

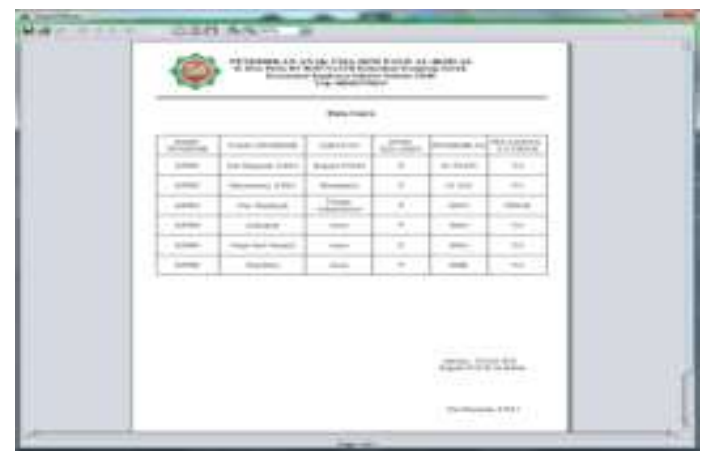

Gambar 16. Tampilan Keluaran Laporan Data Guru
Cetak laporan data guru merupakan keluaran dari laporan data guru yang berisi semua data guru yang diambil dari input-an data guru.

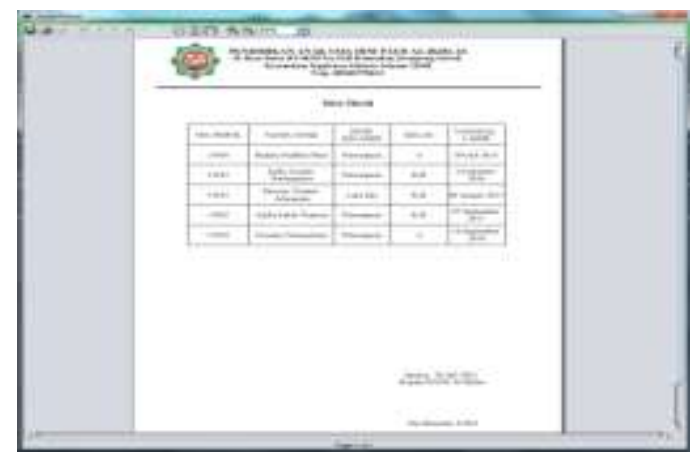

Gambar 17. Tampilan Keluaran Laporan Data Murid

Cetak laporan data murid merupakan keluaran dari laporan data murid yang berisi semua data murid yang diambil dari input-an data murid.

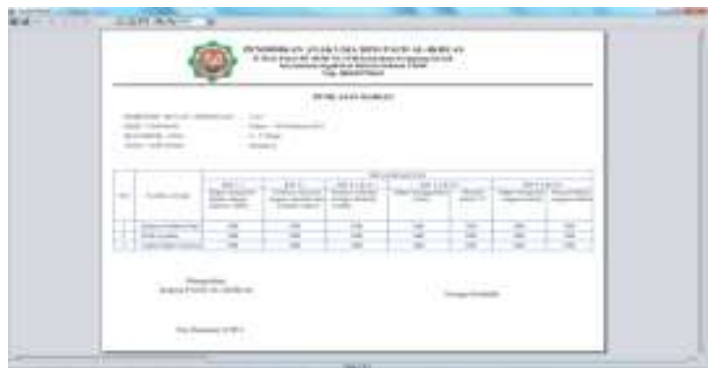

Gambar 18. Tampilan Keluaran Laporan Penilaian Harian

Cetak laporan penilaian harian menampilkan keluaran dari laporan penilaian harian yang di-sorting berdasarkan tanggal. Hanya penilaian harian yang berada pada tanggal yang telah ditentukan yang akan muncul pada laporan.

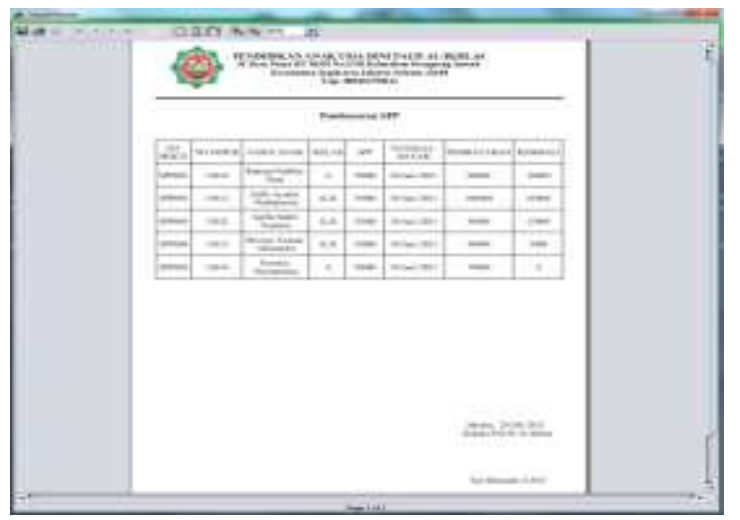

Gambar 19. Tampilan Keluaran Laporan Pembayaran SPP 


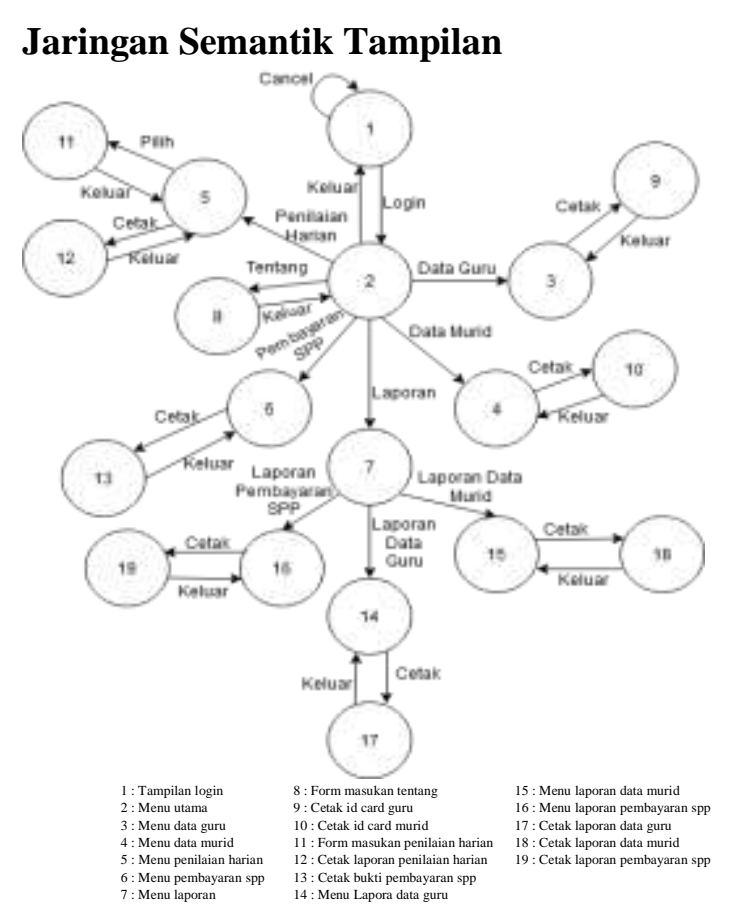

Gambar 20. Jaringan Semantik Tampilan

\section{SIMPULAN DAN SARAN}

Berdasarkan penelitian yang telah dilakukan, didapat beberapa kesimpulan, antara lain:

Sistem informasi administrasi ini telah mampu menjalankan sistem informasi adminstrasi yaitu berupa sistem pendataan guru, sistem pendataan murid, sistem pembayaran SPP, sistem penilaian harian termasuk laporan di dalamnya. Dengan dibuatnya sistem administrasi ini PAUD AlIkhlas tidak memerlukan lagi kartu bayaran yang setiap tahunnya diberikan kepada murid. Pembayaran SPP dapat terselesaikan pada hari itu juga saat akhir bulan menggunakan kertas bukti pembayaran. Penyajian informasi di dalam aplikasi ini dirancang sedemikian rupa sehingga admin dapat dengan mudah memahami informasi yang ada di dalamnya.

Penulis sadar jika aplikasi adminstrasi di PAUD Al-Ikhlas masih banyak kekuranganya, oleh sebab itu peneliti berharap kedepanya aplikasi ini dapat dikembangkan lagi menjadi lebih baik dari sekarang. Berikut saran yang dapat penulis berikan untuk pengembangan aplikasi ini dikemudian hari:

Aplikasi ini masih memiliki tampilan yang belum begitu bagus, peneliti berharap agar tampilan aplikasi ini dapat dikembangkan lebih bagus lagi. Penilaian pada aplikasi ini belum begitu lengkap, dikarenakan begitu banyaknya pengambilan nilai dalam 1 semester. Perlunya penambahan fitur perkelas dalam data murid agar admin mudah memisahkan data murid yang berbeda kelas.

\section{DAFTAR PUSTAKA}

Herliana, A. (2016). Analisa dan Perancangan Sistem Informasi Administrasi Data Pribadi dan Nilai Mahasiswa di Perguruan Tinggi (Studi Kasus Universitas Kebangsaan Bandung). Jurnal Informatika, 1(2), 82-97. https://doi.org/10.31311/ji.v1i2.41

Indrajani. (2015). Database Design. Jakarta: Elex Media Komputindo.

Kadir, A. (2014). Pengenalan Sistem Informasi Edisi Revisi. Yogyakarta: Andi.

Mulyani, S. (2016). Metode Analisis dan Perancangan Sistem. Bandung: Abdi Sistematika.

Muslihudin, M., \& Oktafianto. (2016). Analisis dan Perancangan Sistem Informasi Menggunakan Model Terstruktur dan UML. Yogyakarta: Andi.

Nadeak, B., Parulian, A., Pristiwanto, \& Siregar, S. R. (2016). Perancangan Aplikasi Pembelajaran Internet Dengan Menggunakan Metode Computer Based Instruction. JURIKOM (Jurnal Riset Komputer), 3(4), 54-57. http://ejurnal.stmik-

budidarma.ac.id/index.php/jurikom/arti cle/view/340

Nofriadi. (2015). Java Fundamental Dengan Netbeans 8.0.2. Yogyakarta: Deepublish.

Raharjo, B. (2015). Belajar Otodidak MySQL. Bandung: Informatika.

Sukamto, R. A., \& Shalahuddin, M. (2013). Rekayasa Perangkat Lunak Terstruktur dan Berorientasi Objek. Bandung: Informatika.

Sutabri, T. (2012). Analisis Sistem Informasi. Yogyakarta: Andi.

Trisnadi, F. (2020). Perancangan Aplikasi Pendaftaran Service Motor dan Penjualan Spare Part pada Bengkel Jali. Jurnal Riset Dan Aplikasi Mahasiswa Informatika (JRAMI), 1(02), 282-287. https://doi.org/10.30998/jrami.v1i02.14 5 